\title{
The Impact of Corporate Governance Mechanisms on Audit Quality
}

\author{
Ghodratollah Talebnia $^{1}$, Fatemeh Baghiyan ${ }^{2, *}$, Zahra Baghiyan $^{3}$ \\ ${ }^{1}$ Faculty Member Science and Research Branch of Tehran, Islamic Azad University, Science and Research, Tehran, Iran \\ ${ }^{2}$ Nuclear Science and Technology Research Institute, Plasma Physics and Nuclear Fusion Research School, Azad University of Phd Unit \\ International of Kish, Tehran, Iran \\ ${ }^{3}$ Damavand Unit, Department of Azad University, Tehran, Iran
}

\section{Email address:}

parbag@yahoo.com (F. Baghiyan)

${ }^{*}$ Corresponding author

\section{To cite this article:}

Ghodratollah Talebnia, Fatemeh Baghiyan, Zahra Baghiyan. The Impact of Corporate Governance Mechanisms on Audit Quality. International Journal of Economic Behavior and Organization. Vol. 5, No. 4, 2017, pp. 87-91. doi: 10.11648/j.ijebo.20170504.11

Received: March 24, 2017; Accepted: May 9, 2017; Published: September 26, 2017

\begin{abstract}
The purpose of public research this study was to analyze factors (competition and strategy) which influence or determine the governance structure of (SMF) and effectiveness of government agencies (improved performance and earnings quality by minimizing the likelihood of earnings management) in a theoretical and conceptual framework the official version by the structural equation modeling (SEM) is The specific objectives of this study: 1) implementation of actions and conceptual framework and development model to firms as a case study for images, practical research and discussion in this study developed and 2) analysis of the case study results and the relatively longer countries and studies to make a general conclusion contingency theory. However, it failed to provide any strong evidence on the relationship between corporate governance and performance. The findings show that It is dominated by an approach based on corporate ethics, corporate governance highlights the role of financial control.
\end{abstract}

Keywords: Audit Quality, Corporate Governance Mechanisms, External Auditor, Strategic Management, Management Performance

\section{Introduction}

Recent corporate financial scandals have highlighted the role of corporate governance mechanisms and specifically that of external auditors who are considered a guarantor for the reliability of financial reporting. In fact, the external auditor, who is characterized by his independence and competence, plays a crucial role for investors and financial statement users in their decision making. The choice of a higher quality auditor seems to be very important and it is in most cases the responsibility of the shareholders. In fact, some companies require a certain level of quality for the certification of annual accounts and tend to choose a higher quality auditor, while other firms are not interested in such quality. The assessment of audit quality has attracted considerable attention of the researchers

Because of the lack of consensus on this issue $[9,20,19]$.
Many features are used such as firm size, reputation, experience in audit, industry specialization and the extent to which Information and Communication Technologies (ICT). This differentiation of quality audit has established a strong desire to understand the phenomenon of selection of quality external auditor in the Tunisian context. Indeed, it is quite recognizable that the choice of a higher quality auditor is advantageous for companies; however, it can be used in an opportunistic manner. Studies related to the choice of external auditor have been conducted mainly in the US context $[10,11,12,13$, and 17]. However, there are few empirical studies that examine the decisions of the external auditor choice in developing countries despite the critical impact of such decision on the credibility of firms' financial reporting. The efforts of the Iranian accounting and legal authorities to strengthen the role of the external auditor are expressed through the promulgation of Law No. 2005-96 of 
October 18, 2005 on strengthening financial relations securities. In addition, the scarcity of research concerning the impact of corporate governance mechanisms on the demand for higher audit quality in the context led us to deal with this subject, although most of the firms are considered as Small and Medium Firms (SMF), which in turn can affect the probability of choosing a reputed auditor. In our study, we deal with the following two questions: What are the attributes of audit quality? How do corporate governance mechanisms impact the demand for a reputed auditor? First, our study contributes to the previous literature by addressing the problem of demand for higher quality auditor in the normal operating conditions. Second, our research adopts an original procedure PCA to assess audit quality by exploring the impact of some variables (size, reputation, and experience in audit, industry specialization and the degree to which ICT are used) on the assessment of audit quality rather than using the simple dichotomy (Big Four/Non Big Four). Finally, it checks whether the customer governance mechanisms Are likely to motivate the choice of a reputed auditor in the context. The paper is organized as follows: it discusses the theoretical background of the relationship between corporate governance mechanisms and the choice of higher quality auditor, followed by the presentation of the research methodology and empirical models. Subsequently, it discusses the results, and finally, the conclusion is offered with some limitations. [5] Wright argues in Corporation Nation (2014) that the governance of early U.S. corporations, of which over 20,000 existed by the Civil War of 1861-1865, was superior to that of corporations in the late 19th and early 20th centuries because early corporations governed themselves like "republics", replete with numerous "checks and balances" against fraud and against usurpation of power by managers or by large shareholders Much of the contemporary interest in corporate governance is concerned with mitigation of the conflicts of interests between stakeholders.[6] In large firms where there is a separation of ownership and management and no controlling shareholder, the principal-agent issue arises between upper-management (the "agent") which may have very different interests, and by definition considerably more information, than shareholders (the "principals"). The danger arises that, rather than overseeing management on behalf of shareholders, the board of directors may become insulated from shareholders and beholden to management. [7] This aspect is particularly present in contemporary public debates and developments in regulatory policy. [3] Corporate governance has also been more narrowly defined as "a system of law and sound approaches by which corporations are directed and controlled focusing on the internal and external corporate structures with the intention of monitoring the actions of management and directors and thereby, mitigating agency risks which may stem from the misdeeds of corporate officers." $[1,2]$

Contemporary discussions of corporate governance tend to refer to principles raised in three documents released since 1990: The Cadbury Report (UK, 1992), the Principles of Corporate Governance (OECD, 1999, 2004 and 2015), the
Sarbanes-Oxley Act of 2002 (US, 2002). The Cadbury and Organisation for Economic Co-operation and Development (OECD) reports present general principles around which businesses are expected to operate to assure proper governance. The Sarbanes-Oxley Act, informally referred to as Sarbox or Sox, is an attempt by the federal government in the United States to legislate several of the principles recommended in the Cadbury and OECD reports.

Key parties involved in corporate governance include stakeholders such as the board of directors, management and shareholders. External stakeholders such as creditors, auditors, customers, suppliers, government agencies, and the community at large also exert influence. The agency view of the corporation posits that the shareholder forgoes decision rights (control) and entrusts the manager to act in the shareholders' best (joint) interests. Partly as a result of this separation between the two investors and managers, corporate governance mechanisms include a system of controls intended to help align managers' incentives with those of shareholders. Agency concerns (risk) are necessarily lower for a controlling shareholder. [25]

The Tehran Stock Exchange introduced a corporate governance code in 2007 that reformed "board compensation polices [sic], improved internal and external audits, ownership concentration and risk management. However, the code limits the directors' independence and provides no guidance on external control, shareholder rights protection, and the role of stakeholder rights." [54] A 2013 study found that most Iranian companies "are not in an appropriate situation regarding accounting standards" and that managers in most companies conceal their real performance, implying little transparency and trustworthiness regarding operational information published by them. Examination of 110 companies' performance found that companies with better corporate governance had better performance. [26]

In private for-profit corporations, shareholders elect the board of directors to represent their interests. In the case of nonprofits, stakeholders may have some role in recommending or selecting board members, but typically the board itself decides who will serve on the board as a 'selfperpetuating' board

Rights and equitable treatment of shareholders: [20] [21] [22] Organizations should respect the rights of shareholders and help shareholders to exercise those rights. They can help shareholders exercise their rights by openly and effectively communicating information and by encouraging shareholders to participate in general meetings.

Interests of other stakeholders: [23] Organizations should recognize that they have legal, contractual, social, and market driven obligations to non-shareholder stakeholders, including employees, investors, creditors, suppliers, local communities, customers, and policy makers.

Role and responsibilities of the board: [24] [25] The board needs sufficient relevant skills and understanding to review and challenge management performance. It also needs adequate size and appropriate levels of independence and commitment. 
Integrity and ethical behavior: [26] [27] Integrity should be a fundamental requirement in choosing corporate officers and board members. Organizations should develop a code of conduct for their directors and executives that promotes ethical and responsible decision making.

Disclosure and transparency: [28, 29] Organizations should clarify and make publicly known the roles and responsibilities of board and management to provide stakeholders with a level of accountability. They should also implement procedures to independently verify and safeguard the integrity of the company's financial reporting. Disclosure of material matters concerning the organization should be timely and balanced to ensure that all investors have access to clear, factual information

In a general classification mechanism for this include both within the organization and outside the organization.

Mechanisms within the organization:

Internal mechanisms (inscribed) include:

a. Board: The Executive Board and the establishment of strong, reputable and impartial

b. The executive management division of responsibilities between the executive and the establishment of suitable software

c. Non-Executive management: the creation of a committee of independent directors and non-executive board (including the Audit Committee, rights, etc.)

d. Internal controls: design, development and deployment of appropriate internal controls

e. Corporate ethics: the development and expansion of the professional code of ethics and organizational ethics

External mechanisms:

Mechanisms of external (environmental) are:

A. Regulated: the formulation, adoption and implementation of appropriate regulations.

B. Legal system: establishing an appropriate legal system.

C. The efficiency of capital markets: the development of the capital market and enhance its efficiency.

D. Monitoring major shareholders: motivate shareholders to activities such as buy a controlling stake.

E. The role of institutional shareholders: encourage and expand institutional investors.

F. Monitoring the minority shareholders: respect for the rights of minority shareholders and the legality of monitoring the activities of minorities.

G. Require independent audits according to its regulatory role.

$\mathrm{H}$. The activities of rating agencies: facilitating activities of rating agencies.

According to [9], majority shareholders have the power to influence decisions made by the general assembly of shareholders and require the implementation of several external governance mechanisms (external auditors, committees, etc.), in order to protect their investments and ensure effective monitoring of managers. Based on the agency theory, $[1,2,3]$ show that companies tend to use the services of a higher quality auditor when agency problems (as the conflicts of interests) are more pronounced $[5,6,7$,
8], State that the demand for a higher quality auditor is positively related to the presence of majority shareholders. [10] Confirms the idea that managers possessing a significant portion of equity capital can use their voting rights to take control (management buyout). They can sometimes influence the control of companies and lead the management to make decisions which promote their positions, such as the nomination of a higher quality auditor $[5,6]$. Similarly, there are large communication difficulties for larger board firms, which preclude the process of decision making by managers. $[14,15,16]$, reach a similar conclusion and consider that a small size board of directors is more effective than a larger board, since it is able to monitor the strategic decisions taken by managers and reduce their discretionary behavior. Further, when the size of the board is large, the role of monitoring is considered as more important. Thus, we stipulate a positive relationship between the board size and the choice of higher quality auditor. In fact, reputed auditors are considered as guarantors of information quality and efficient monitoring.

By focusing on internal governance mechanisms of the company, researchers, [11, 12], argue that the board must ensure similar interests between director and shareholders. The duality of the manager as the chairman of the board is a negative sign for corporate governance quality. In addition, it can lead to the development of manipulation and corruption within the company associated with a lack of information transparency and weaknesses in the internal control system. $[18,9,11]$ show that a lower level of corporate governance is associated with a higher level of earnings management and CEO duality.

Corporate governance literature [10] suggests that independent directors are synonymous with strong corporate governance structure. The influence of independent directors on the effectiveness of the board of directors has attracted the attention of many researchers.

Based on the assumptions of agency theory, increasing effective functioning of the board is generally attributed to the presence of independent directors [5, 6, and 8].

Many studies including [20, 19, and 1] suggest that the size of the audited firm is a crucial determinant of the choice of a reputed auditor.

\section{Research Hypotheses}

It is argued that companies in competitive industries, tend to have weaker corporate governance, such as competition reduces the agency problems, while government agencies tangible and intangible costs may be high.

1. Given the role or purpose of the rule firm, principled argument claims that government agencies should be able to achieve both roles (performance and corporate governance / financial control role) to coincide Zvr.

2. However, the principles discussed as the role of financial control management flexibility, resulting in poor performance has been challenged.

Henry asked and [7, 8] argued that the balance between control and financial and strategic management roles, 
depending on organizational and environmental context in which the company operates there.

\section{Data Description}

This study applies structural equation modeling (SEM) and makes use of analysis of structures moment (AMOS) for data analysis, because it allows to evaluate the reliability and validity of the indicators in a complex structure such as government agencies and business strategy and enterprises.

It may also examine a series of dependency relationships between variables and hidden structures, as well as between different structures simultaneously in this study, has been developed.

Table 1. Attributes of Audit Quality.

\begin{tabular}{ll}
\hline 1. & Variable \\
2. & Label \\
3. & Measure \\
4. & Audit Size \\
5. & TCA Total number of employees in audit firm. \\
6. & Reputation \\
7. & REP \\
8. & A dummy variable which equals 1, if the audit firm \\
9. & belongs to the 'Big Ten' firms, or 0 otherwise. \\
10. & Experience \\
11. & EXP Number of years of experience in audit field. \\
12. & Sector Specialization \\
13. & SPEC A dummy variable which equals 1, if the audit firm is \\
14. & specialized in a particular sector, or 0 otherwise. \\
15. & The Extent to Which ICT are Used \\
16. & ICT \\
17. & A dummy variable which equals 1 if the firm uses \\
18. & computer software in audit missions, and 0 \\
19. & otherwise \\
\hline
\end{tabular}

Table 2. Determinants of Audit Quality.

\begin{tabular}{ll}
\hline 1. & Predicted \\
2. & Sign \\
3. & Measure \\
4. & Variable \\
5. & Label \\
6. & Majority Shareholders MAJ \\
7. & Percentage of shares held by major shareholders \\
8. & + \\
9. & Director Ownership \\
10. & MAN \\
11. & Percentage of shares held by the director \\
12. & - \\
13. & Institutional Investors \\
14. & INST \\
15. & Percentage of shares held by institutional investors \\
16. & - \\
17. & Board Size \\
18. & B_SIZE Total number of directors in the board \\
19. & + \\
20. & Duality \\
21. & DUAL \\
22. & A dummy variable which equals 1, if the CEO \\
23. & is also the president of the board, or 0 \\
\hline
\end{tabular}

\begin{tabular}{ll}
\hline 24. & otherwise \\
25. & + \\
26. & Independent Directors \\
27. & IND_DIR Number of independent directors divided by the \\
28. & total number of directors \\
29. & + \\
30. & Firm Size \\
31. & F_SIZE \\
32. & Natural logarithm of total assets \\
33. & + \\
34. & Leverage \\
35. & LEV \\
36. & Total debt divided by total assets \\
37. & + \\
\hline
\end{tabular}

\section{Conclusion}

These findings suggest that business competition as an environmental factor and organizational strategies as an effective corporate governance structure. Market competition as a replacement rule is reasonable. The firms. Type of advocacy strategies have often found that stronger corporate governance. It could lead to its corporate governance structure. Companies may not only review the regulations, but also examine the business environment and strategy. It also showed that the firm can rule as a risk management mechanism in reducing risks. In particular, used accounting However, it failed to provide any strong evidence on the relationship between corporate governance and performance. The findings show that It is dominated by an approach based on corporate ethics, corporate governance highlights the role of financial control.

\section{References}

[1] The Corporate Governance of Iconic Executives, 87 Notre Dame Law Review 351 (2011), available at: http://ssrn.com/abstract=2040922

[2] Goergen, Marc, International Corporate Governance, (Prentice Hall 2012) ISBN 978-0-273-75125-0.

[3] Sytse Douma \& Hein Schreuder (2013) "Economic Approaches to Organizations", 5th edition, London: Pearson [2].

[4] Sifuna, Anazett Pacy (2012). "Disclose or Abstain: The Prohibition of Insider Trading on Trial". Journal of International Banking Law and Regulation. 27 (9).

[5] Robert E. Wright, Corporation Nation (Philadelphia: University of Pennsylvania Press, 2014).

[6] Abbott L J and Parker S (2000), "Auditor Selection and Audit Committee Characteristics", Auditing: A Journal of Practice and Theory, Vol. 19, No. 2, pp. 47-66.

[7] Abdel-Khalik A R (1993), "Why Do Private Companies Demand Auditing? A Case for Organizational Loss of Control", Journal of Accounting, Auditing and Finance, Vol. 8 , No. 1, pp. 31-52. 
[8] Steven N. Kaplan, Executive Compensation and Corporate Governance in the U.S.: Perceptions, Facts and Challenges, Chicago Booth Paper No. 12-42, Fama-Miller Center for Research in Finance, Chicago, July 2012.

[9] Adjaoud F, Mamogli F and Siala F (2008), "Auditor Reputation and Internal Corporate Governance Mechanisms: Complementary or Substitutable?", Review of Business Research, Vol. 8, No. 1 (January).

[10] Aldesier G R, Miller J R and Moraglio J F (1995), "Common Attributes of Quality Audits", Journal of Accountancy, Vol. 179, No. 1, pp. 61-70.

[11] Baker C R and Wallage P (2000), "The Future of Financial Reporting in Europe: Its Role in Corporate Governance", The International Journal of Accounting, Vol. 35, No. 2, pp. 173187.

[12] Beasley M S and Petroni K R (2001), "Board Independence and Audit Firm Type", Auditing: A Journal of Practice and Theory, Vol. 20, No. 1, pp. 96-114.

[13] Brickley J, Lease R and Smith C (1988), "Ownership Structure and Voting on Anti-Takeover Amendments", Journal of Financial Economics, Vol. 20, pp. 267-291. 8.

[14] Bushee B and Noe (2000), "Corporate Disclosure Practices, Institutional Investors and Stock Return Volatility", Journal of Accounting Research, Vol. 38 (Supplement), pp. 171-202.

[15] Carcello J V, Hermanson R H and McGrath N T (1992), "Audit Quality Attributes: The Perceptions of Audit Partners, Preparers, and Financial Statement Users", Auditing: A Journal of Practice and Theory, Vol. 11, No. 1, pp. 1-15.

[16] Charreaux G (1994), Conseil d'administration et pouvoirs dans l'entreprise, Revue d'Économie Financière, No. 31.

[17] Chow C W (1982), "The Demand for External Auditing: Size, Debt and Ownership Influences", The Accounting Review, Vol. 57, No. 2, pp. 272-291.

[18] Cohen J, Krishnamoorthy G and Wright A M (2002), "Corporate Governance and the Audit Process", Contemporary Accounting Research, Vol. 19, No. 4, pp. 573594.
[19] Copley P A and Douthett E B (2002), "The Association Between Auditor Choice, Ownership Retained and Earning Disclosure by Firms Making Initial Public Offering", Contemporary Accounting Research, Vol. 19, No. 1.

[20] Craswell A T, Francis J R and Taylors L (1995), "Auditor Brand Name Reputations and Industry Specialization", Journal of Accounting and Economics, Vol. 20, No. 3, pp. 297-332.

[21] Daily C and Dalton D (1993), "Board of Directors Leadership and Structure: Control and Performance Implications", Entrepreneurship Theory and Practice, Vol. 17, No. 3, pp. 6581.

[22] Danos P and Eichenseher J (1982), “Audit Industry Dynamics: Factors Affecting Changes in Client Industry Market Shares", Journal of Accounting Research, Part II, pp. 604-616, Autumn.

[23] DeAngelo L (1981), “Auditor Size and Quality", Journal of Accounting and Economics, Vol. 3, No. 2, pp. 183-199.

[24] Dechow P M, Sloan R G and Sweeney A P (1996), "Causes and Consequences of Earnings Manipulation: An Analysis of Firms Subject to Enforcement Actions by SEC", Contemporary Accounting Research, Vol. 13, No. 1, pp. 1-36.

[25] Depoers F (2000), "A Cost-Benefit Study of Voluntary Disclosure: Some Empirical Evidence from French Listed Companies", The European Accounting Review, Vol. 9, No. 2, pp. 245-263.

[26] Dent, George W., Corporate Governance Without Shareholders: A Cautionary Lesson from Non-Profit Organizations (2014). Delaware Journal of Corporate Law (DJCL), Vol. 39, No. 1, 2014; Case Legal Studies Research Paper No. 2014-34. Available at SSRN.

[27] Dumontier P, Chtourou S and Ayedi S (2006), La qualité de l'audit externe et les mécanismes de gouvernance des entreprises: Une étude empirique menée dans le contexte tunisien, Actes du27ème congrès de l'Association Francophone de Comptabilité (AFC), Tunisia. 